\title{
VERTINIMAS KAIP UŽSIENIO KALBOS MOKYMO(SI) DALIS, PAŽANGOS IR PASIEKIMŲ RODIKLIS VILNIAUS KOLEGIJOS ELEKTRONIKOS IR INFORMATIKOS BEI VERSLO VADYBOS FAKULTETŲ STUDENTŲ IR DĖSTYTOJŲ POŽIŪRIU
}

\author{
Jūratė Helsvig, Aušra Netikšienè, Jūratė Patackaitė
}

Vilniaus kolegijos Užsienio kalbų centras

\begin{abstract}
Anotacija. Studentu mokymosi pasiekimu lygis yra vienas pagrindiniu aukštosios mokyklos administracijos, dèstytoju ir studentu tarpusavio bendradarbiavimo veiklos rodikliu, kurie profesinejje aplinkoje turi ịtakos absolventu profesiniu žiniu igijimui ir gebejjimu išsiugdymui bei lemia jų konkurencinguma tarp tos pačios srities specialistu. Todèl, kaip teigiama LR ŠMM ir S̆MPF 2018 m. parengtame rekomendaciju squade, svarbi ,, $i$ studenta orientuoto mokymosi, mokymo ir pasiekimu vertinimo dermé". Vertinimas yra aktuali tema tiek dèstytojui, tiek studentui. Studentas gali ịsivertinti pažanga, igytas žinias ir gebejjimus, sustiprinti ar prarasti motyvacija, siekdamas geresniu rezultatu; dèstytojas gali isivertinti savo dèstomo dalyko efektyvuma, mokymo kokybę ir žiniu ar patirties perteikima. Gera vertinimo praktika ir patirtis skatina mokymasi, padeda siekti mokymo ir mokymosi kokybès. Straipsnio autorès neabejoja temos aktualumu ir tuo, kad vertinimo efektyvuma lemia tinkamai parinkti vertinimo tipai, suplanuoti vertinimo metodai bei tinkamai paruoštos užduotys ir ju vertinimo kriterijai. Déstytoju ir studentu tarpusavio bendradarbiavimas ypač svarbus, pasirenkant vertinimo metodus, kurie ne tik parodytu rezultatus, bet ir skatintu tiek dèstytojus, tiek studentus tobulèti.
\end{abstract}

Pagrindiniai žodžiai: vertinimas, užsienio kalba, pasiekimai, formalusis vertinimas, neformalusis vertinimas.

Problema. Kvalifikuota vertinimo proceso svarba yra ypač aktuali studentams dèl galimybės, kuri atsiranda tik studentui pasiekus puikų arba tipini pasiekimų lygmeni, tęsti studijas valstybès lèšomis, o dèstytojui - atsakomybė ir pareiga būti kvalifikuotam vertintojui. Kvalifikuoto (kokybiško) vertinimo nebuvimas gali ne tik sumažinti studentų motyvaciją bei pasitikèjimą dèstytoju, aukštaja mokykla, bet ir atimti laiko, finansų ar net norą toliau tęsti mokslus. Nors tiek Bendrieji Europos kalbų metmenys (BEKM), tiek aukštosios mokyklos pasiekimų lygio politika yra paremti studentų žinių ir gebejjimų įsivertinimu, t. y. sąmoningu mokymusi, mokejjimu nusistatyti ir sekti savo išmokimo lygị ir ịgyti gebejjimų parengti tobulejjimo bei mokymosi visą gyvenimą planą, suteikia prielaidų formuojamajam vertinimui, aukštosiose mokyklose taikomas kriterinis (kaupiamasis) vertinimas. Straipsnio 
autorès neabejoja temos aktualumu ir tuo, kad vertinimo efektyvumą lemia tinkamai parinkti vertinimo tipai, suplanuoti vertinimo metodai bei tinkamai paruoštos užduotys ir jų vertinimo kriterijai, taip pat dèstytojų ir studentų tarpusavio bendradarbiavimas. Tad gal ir neformaliajam vertinimui reikètų rasti vietą vertinant aukštosios mokyklos studentus. Juk ar ne studentų tobulëjimu ir nuolatiniu dėstytojų kvalifikacijos kèlimu pagrịsta visa aukštojo mokslo sistema?

Objektas: vertinimas kaip užsienio kalbos mokymo(si) dalis bei pažangos ir pasiekimų rodiklis Vilniaus kolegijos Elektronikos ir informatikos ir Verslo vadybos fakultetų studentų ir dėstytojų požiūriu.

Tikslas - išsiaiškinti apklausos ir interviu metodais Vilniaus kolegijos Elektronikos ir informatikos, Verslo vadybos fakultetų studentų ir Užsienio kalbų centro dėstytojų požiūrị ị vertinimą, palyginti ịvairių kursų studentų ir dẻstytojų požiūrị ir ịvertinti vertinimo tipų privalumus, trūkumus ir galimybes studentų užsienio kalbų rezultatams Vilniaus kolegijoje pasiekti.

\section{Vertinimo, įvertinimo ir ịsivertinimo sampratų apibūdinimas}

LR švietimo ir mokslo ministras dar $2004 \mathrm{~m}$. ịsakymu pateikė vertinimo, iqvertinimo ir ịsivertinimo sampratas, kuriomis vadovaujamasi Lietuvos bendrojo lavinimo ir aukštosiose mokyklose. Šie apibūdinimai tokie: „Vertinimas - nuolatinis informacijos apie mokinio / studento mokymosi pažangą ir pasiekimus kaupimo, interpretavimo ir apibendrinimo procesas. İvertinimas - vertinimo proceso rezultatas, konkretus sprendimas apie mokinio / studento pasiekimus ir padarytą pažangą. İsivertinimas - paties mokinio / studento daromi sprendimai apie daromą pažangą bei pasiekimus“ (Mokinių pažangos ir pasiekimų vertinimų samprata, (MPPVS), patvirtinta Lietuvos Respublikos švietimo ir mokslo ministro $2004 \mathrm{~m}$. vasario 25 d. įsakymu Nr. ISAK-256). Užsienio literatūroje dar $1994 \mathrm{~m}$. vartojamas toks apibūdinimas: „Vertinimas - tai ịvairių faktų apie mokymąsi rinkimas, mokymosi rezultatu nustatymas ir matavimas (Gage, Berliner, 1994).

Tačiau šiame straipsnyje demesys bus skiriamas vertinimui ir vertinimo tipams, kurie skirstomi pagal paskirtị: ị formuojamajị, diagnostinị ir apibendrinamaji

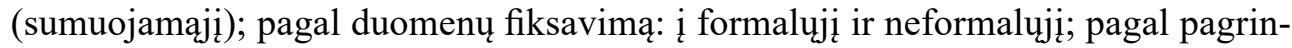
dimą: ị kriterinị, idiografinị ir norminị; pagal subjektus - ị kitų vertinimą (pvz., dèstytojo, studijų kolegos) ir t. t.

Panagrinėsime dažniausiai taikomus vertinimo tipus - formuojamajji ir apibendrinamaji (sumuojamajii). Mokslinejje literatūroje jie dar vadinami vertinimais, skirtais mokymuisi (assessment for learning) ir mokymosi rezultatu vertinimais (assessment of learning). Šie vertinimo tipai skiriasi savo tikslais, metodais ir vertinimo rezultatu panaudojimais. Formuojamojo vertinimo tikslas yra pagerinti mokymą(si) teikiant pastovų grịžtamajị ryši, kai tuo tarpu sumuojamojo vertinimo tikslas yra įvertinti studento mokymąsi, mokymosi pasiekimus palyginant su standartu. Formuojamaji vertinimą atlieka ne tik déstytojas, bet ir patys studentai, jų 
bendramoksliai, taikydami ịvairius mokymo(si) ir vertinimo metodus. Sumuojamąji (apibendrinamaji) vertinimą atlieka tik dėstytojas, dažniausiai skyriaus, semestro pabaigoje ịvertindamas studentų išmokimą, kad būtų galima daryti išvadas apie tai, kas pasiekta ir ko nepavyko pasiekti. Dėstytojas rašo pažymị už atliką užduotị ir pažymys sumuojamas mokomojo dalyko pabaigoje. Formuojamasis vertinimas yra nuolatinis procesas, vykstantis visuose mokymosi proceso etapuose, jo metu nerašomas galutinis pažymys nei rašto darbo pabaigoje, nei pažymių knygelèje. Trumpai tariant, vertinimas, skirtas mokymuisi, yra formuojamasis, neformalusis, ir nukreiptas į mokymosi procesą, kai tuo tarpu mokymosi rezultatų vertinimas yra apibendrinamasis (sumuojamas), formalusis, ir nukreiptas į mokymosi rezultatą.

Ugdymo procese yra svarbus tiek mokymosi rezultatų vertinimas, tiek vertinimas, skirtas mokymuisi, tačiau pastarasis yra kur kas galingesnis vertinimo įrankis, jei norima skatinti studentų mokymąsi ir ilgalaikę motyvaciją.

Aukštojoje mokykloje reikalingi abu vertinimo tipai, nes, viena vertus, dèstytojas turi rašyti pažymį, kita vertus, turi aiškiai studentui pateikti išsamų grižtamaji ryši ir nurodyti tolesnio tobulejjimo galimybes. Vis labiau akcentuojant studijas, orientuotas i studentą, bei studentu autonomiškumą visame mokymosi procese, $i$ vertinimo procesą vis labiau įtraukiami ir studentai. Vertinimo procese aktyviai dalyvauja ne tik desstytojas, bet ir pats studentas, nuolat įsivertindamas savo paties daromą pažangą ir atitiktị lūkesčiams, bei kiti grupès studentai (peer). Studentų itraukimas ị vertinimo ir ịsivertinimo veiklas sudaro prielaidas puoselèti vertinimo kultūrą, kai dėmesys skiriamas ne tik matavimui ir įvertinimui, bet mokymuisi ir ịsivertinimui. Tokios kultūros puoselèjimas padeda studentams prisiimti atsakomybę už savo mokymąsi, ugdytis savarankiško mokymosi gebejjimus. Jiems reiktų suteikti daugiau galimybių apmąstyti savo mokymąsi ir rezultatus. Studentu ì (si)traukimas ị pasiekimų vertinimų gairių kūrimą akcentuojamas rekomendacijų , „I studentą orientuoto mokymosi, mokymo ir pasiekimų vertinimo dermë“ sąvade: „Studentai turètų aktyviai ịsitraukti ị kasdienes studijų aktualijas ir vertinimo procesą bendradarbiaudami, išsakydami nuomonę, teikdami pasiūlymus ir taip stimuliuodami pasiekimų vertinimo kultūros kaitą. Aukštoji mokykla turètų būti atsakinga ir sudaryti galimybes studentams tinkamai dalyvauti vertinimo procese ir diskusijose apie mokymosi tobulinimą, nes studentai ị aukštąsias mokyklas ịstoja su skirtinga mokymosi patirtimi, gebejjimais ir nevienodai suprasdami aukštojo mokslo studijas."

\section{Studentų pasiekimų vertinimo (vertinimo struktūros, vertinimo metodų ir vertinimo kriterijų) Vilniaus kolegijoje apžvalga}

Vilniaus kolegijoje (toliau - VK) dèstytojai vadovaujasi „Vilniaus kolegijos studijų tvarka", kurios paskirtis - nustatyti studijų Vilniaus kolegijoje sistemą, sąlygas, organizavimą ir vykdymą, kolegijos studentų ir klausytojų teises bei pareigas, „Studijų rezultatų vertinimo tvarkos aprašu“, kuris nustato dalyko (modulio) studijų rezultatų vertinimo principus ir tvarką Vilniaus kolegijoje, fakultetų dekanų 
ịsakymu „Dèl laiku neatliktų ar neigiamai įvertintų tarpinių atsiskaitymų sąlygų“. Minètuose dokumentuose apibrèžta vertinimo samprata, principai bei nubrèžtos pagrindinès su vertinimu susijusios sąlygos. Vertinimo tikslas - įvertinti studentų pasiektus studijų rezultatus ir jų lygị, teikti studentui grižtamają informaciją apie pasiekimus, daromą pažangą. Vertinant privaloma vadovautis tokiais principais kaip pagrịstumas, patikimumas, aiškumas, naudingumas, nešališkumas. Studijų rezultatụ vertinimas susideda iš žinių vertinimo, gebejjimų vertinimo ir nuostatų vertinimo. Kolegijoje taikomas kaupiamasis kriterinis vertinimas. Dalyko (modulio) studiju rezultatai vertinami balais nuo 1 iki 10 . Balas yra studijų programos rezultatų pasiekimo matas. Dalyko (modulio) vertinimo tvarka yra ịtraukta ị dalyko (modulio) programos aprašą, suderintą katedroje, kuriai priskirtas dalykas (modulis). Dalyko (modulio) baigiamajị ịvertinimą sudaro tarpinių atsiskaitymų įvertinimų, padaugintų iš jiems suteiktų atitinkamų svertinių koeficientų, suma. Dėstytojas, paskelbęs vertinimo rezultatus, turi informuoti besidominčius studentus apie pagrindinius jų darbo trūkumus ir klaidas. Dalyko (modulio) apraše išsamiai pateikiama studiju rezultatų vertinimo sistema: modulio studijų rezultatai, studijų metodai, studentų pasiekimų vertinimo metodai, vertinimo struktūra ir kriterijai.

\section{Užsienio kalbụ mokymo ir vertinimo situacijos apžvalga Elektronikos ir informatikos ir Verslo vadybos fakultetuose}

Elektronikos ir informatikos fakultete (toliau - EIF) yra dèstoma anglų kalba 1, anglų kalba 2, profesinè anglų kalba, specialybès anglų kalba. Kalbų studijoms skiriami 6 kreditai vienai studiju programai. Verslo ir vadybos fakulteto (toliau VVF) studijų programose yra verslo užsienio kalba (pirmoji), jau keletą metų dėstoma tik anglų kalba, verslo užsienio kalba (antroji) - vokiečių kalba ir užsienio kalba, kur studentai gali patys pasirinkti iš siūlomų užsienio kalbų: prancūzų, rusų, ispanų, italų, kinų, danų, švedų.

Užsienio kalbos dalyko (modulio) baigiamaji ịvertinimą sudaro tarpiniai atsiskaitymai, igyti semestro eigoje (70 proc.), ir egzaminas raštu, atliekamas semestro pabaigoje (30 proc.). Kiekvienam tarpiniam atsiskaitymui dėstytojas parengia vertinimo kriterijus atskirai, vadovaudamasis Bendraisiais Europos kalbų mokymosi, mokymo ir vertinimo metmenimis bei Užsienio kalbų centro ir katedrų, kuruojančių studiju programas, rekomendacijomis. Formaliai vertinami šie specialieji (užsienio kalbos) gebejjimai: rašymas, klausymas, kalbèjimas ir skaitymas. Dažniausiai užsienio kalbų mokyme taikomi šie vertinimo metodai: apklausa žodžiu, apklausa raštu, pranešimo pristatymas, užsienio kalbos mokymosi pasiekimų aplankas.

Elektronikos ir informatikos fakultete vertinimo struktūra ir jų įtaka galutiniam pažymiui pasiskirsčiusi šitaip: kontrolinis darbas (jo ịtaka galutiniam pažymiui 20 proc.), praktinès užduotys (30 proc.), savarankiškas darbas (20 proc.), egzaminas (30 proc.). Verslo vadybos fakultete studentų žinios ir gebejimai vertinami tokiu būdu: apklausa raštu ir žodžiu sudaro 20 proc. bendro modulio ver- 
tinimo, apklausa raštu (kontrolinis darbas, testas) - 10 proc., pranešimo pristatymas - 20 proc., užsienio kalbų mokymosi pasiekimų aplanko užduočių pristatymas 20 proc. ir egzaminas raštu - 30 proc. Ši vertinimo struktūra gali būti atnaujinama pateikus studijų programos komitetui argumentuotus pasiūlymus, taip pat kiekvienos studijų programos komitetas gali pateikti rekomendacijų dèstytojui, koordinuojančiam užsienio kalbos dalyką (modulį), dèl vertinimo struktūros atnaujinimo.

\section{Vertinimas Vilniaus kolegijos EIF ir VVF studentų ir dėstytojų požiūriu}

Apklausa buvo atlikta Vilniaus kolegijos Elektronikos ir informatikos fakultete ir Verslo vadybos fakultete. Apklausoje dalyvavo 149 I-III kursų studentai, iš kuriu 52 EIF studentai ir 97 VVF studentai, kurie mokèsi ar mokosi užsienio kalbos, taip pat Užsienio kalbų centro (toliau - UKC) lektoriai. Šia apklausa siekta išsiaiškinti, kaip vertinimą supranta VK dviejų fakultetų studentai, ar studentų ir dèstytojų požiūriai šiuo klausimu panašūs, taip pat ar dabar taikomas kaupiamasis (suminis, apibendrinamasis, formalusis) vertinimas skatina studentus tobulèti ir aktyviai dalyvauti paskaitose, dirbti savarankiškai namuose ir ar užtikrina objektyvų rezultatų vertinimą, kitaip tariant, ar toks vertinimas tinka studentų užsienio kalbos žinių ir gebejjimų pažangai ir pasiekimams ịvertinti.

Vertinimo efektyvumas labai priklauso ir nuo pasirinktų vertinimo kriterijų. Užsienio kalbos modulio / dalyko vertinimo kriterijai yra pristatomi studentams kurso pradžioje. Apklausoje norejome sužinoti, ar studentams yra aiškūs užsienio kalbos modulio / dalyko vertinimo kriterijai. Didžioji apklaustų studentų dalis teigè, kad vertinimo kriterijai yra visiškai aiškūs (86 studentai) arba aiškūs (54 studentai), t. y. 94 proc. visų apklaustujų (žr. 1 pav.).

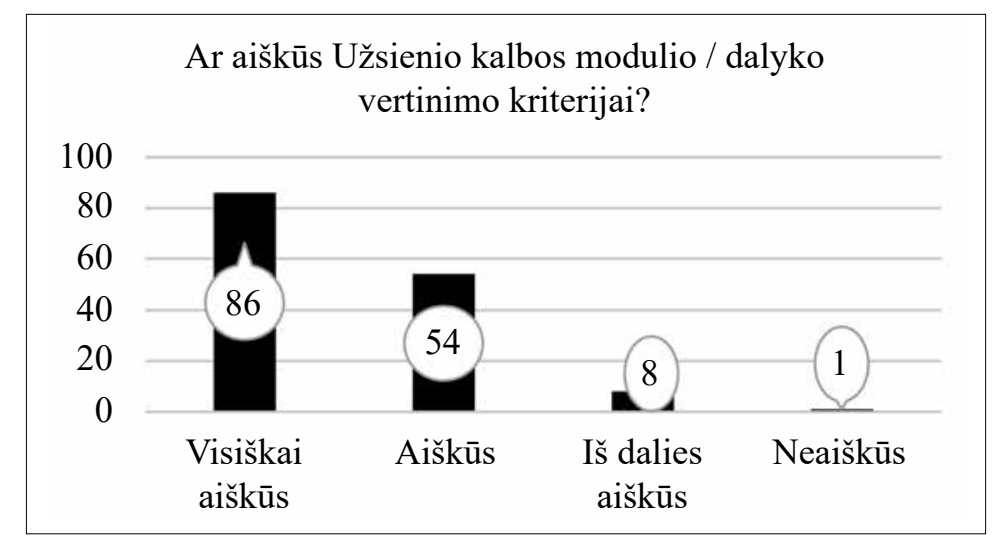

1 pav. Užsienio kalbos modulio / dalyko vertinimo kriterijų samprata

VK taikomas kaupiamasis vertinimas, kuriuo dèstytojai vertina studentų pasiekimus - igytas žinias ir gebejjimus, padarytą pažangą taikant įvairius vertinimo metodus. Užsienio kalbos žinios ir gebejjimai yra vertinami balu / pažymiu. Apklau- 
soje siekta išsiaiškinti, ką studentai mano apie vertinimą balais. 97 proc. apklaustųjų pažymejjo, kad vertinimas balais jiems yra svarbus. Atlikta apklausa parodé, kad vertinimas balais ne tik skatina mokytis ir didina mokymosi motyvaciją, bet taip pat padeda suprasti žinių lygį, suvokti savo galimybes ir mokytis iš klaidų (žr. 2 pav.).

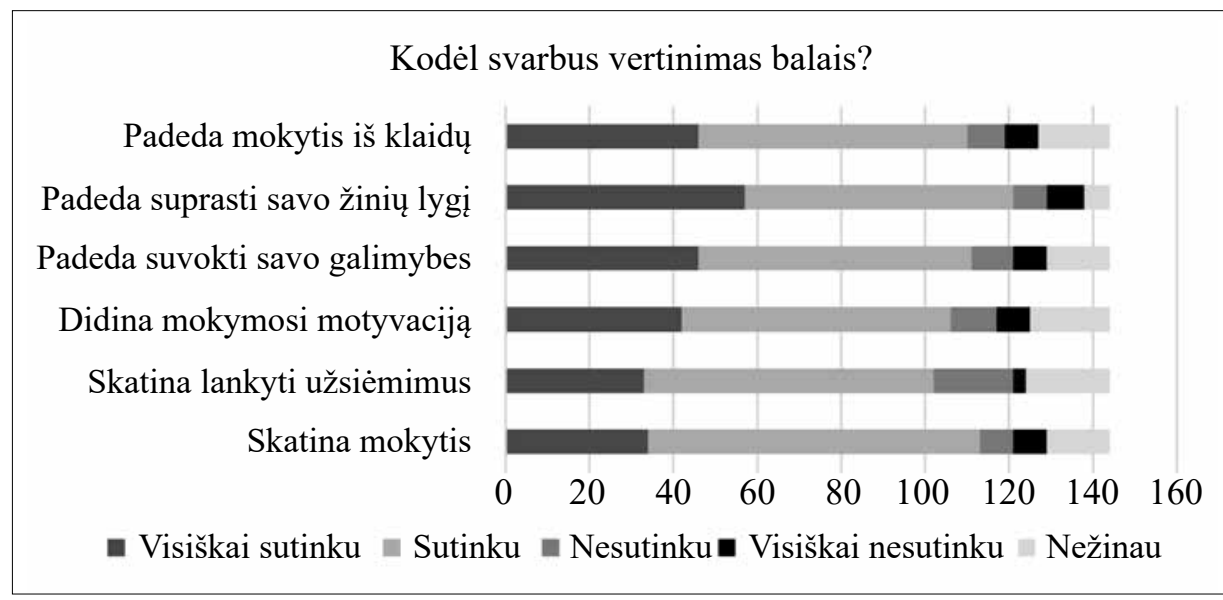

2 pav. Vertinimo balais svarba

Apklausoje pateikta keletas vertinimo tipų (žr. 1 lentelę), kuriuos paprašyta atpažinti. Gauti rezultatai (žr. 3 pav.) patvirtino, kad UKC dèstytojai, vertindami studentus, remiasi standartais / kriterijais. Baigus temą ar kurso dalị studentų pasiekimai yra tikrinami, tai tik patvirtina taikomą kaupiamajji vertinimą. Studentai taip pat pažymėjo, kad jų mokymąsi dėstytojas nuolat stebi, komentuoja ir aptaria pasiekimus. Džiugu ir tai, kad studentai (73 proc.) patys lygina savo pasiekimų rezultatus su ankstesniais.

\section{1 lentelè. Vertinimo tipai}

\begin{tabular}{|c|l|}
\hline 1 & Dėstytojas nuolat stebi mano mokymąsi, komentuoja, aptaria mano pasiekimus. \\
\hline 2 & $\begin{array}{l}\text { Noredamas padėti, nukreipti tam tikrai veiklai, dėstytojas mane įvertina žodžiu ar raštu, bet ne } \\
\text { balu. }\end{array}$ \\
\hline 3 & $\begin{array}{l}\text { Prieš pradedant naują mokymosi temą, kursą, dėstytojas žodžiu ar raštu patikrina mano } \\
\text { pasiekimus. }\end{array}$ \\
\hline 4 & Baigus temą ar kurso dalį, dėstytojas žodžiu ar raštu patikrina mano pasiekimus. \\
\hline 5 & Vertindamas pasiekimus dėstytojas remiasi tam tikrais standartais (kriterijais). \\
\hline 6 & $\begin{array}{l}\text { Vertindamas dabartinius mano pasiekimus dėstytojas juos lygina su ankstesniais, taip } \\
\text { stebėdamas mano pažangą. }\end{array}$ \\
\hline 7 & Aš pati / pats lyginu pasiekimus su ankstesniais. \\
\hline
\end{tabular}


Rezultatai, pateikti 3 pav., rodo vertinimo svarbą pasiekimams ir tai, kad apklausti studentai atpažįsta šiuos vertinimo tipus. Išsakydami savo nuomonę dèstytojai pažymi, kad vertinimas yra skirtas pasiekimams ir pažangai nustatyti bei yra visapusiškas, nes vertinamos žinios ir gebėjimai. Šiuo požiūriu tiek studentų, tiek dèstytojų nuomonès sutampa.

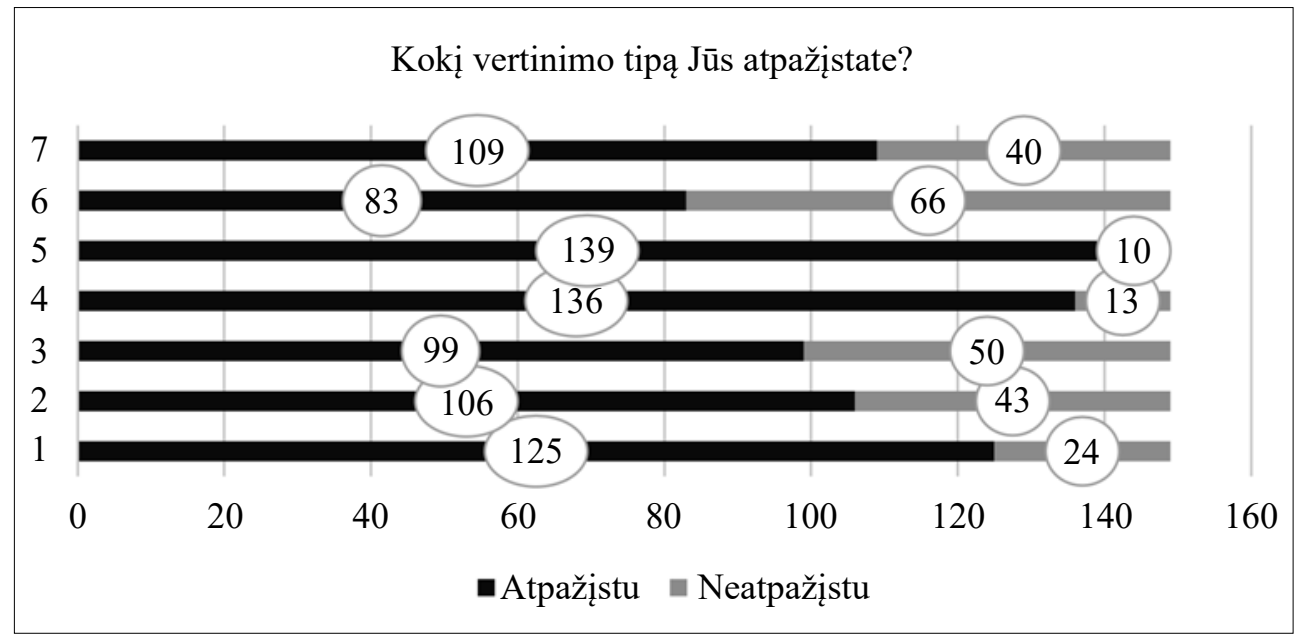

3 pav. Vertinimo tipų identifikavimas

Siekdamos išsiaiškinti, kaip vertinimo paskirtị supranta studentai ir dèstytojai, pateikème teiginius (žr. 3 lentelę) ir paprašème ịvertinti sutikimo su kiekvienu teiginiu mastą. Apžvelgdamos rezultatus panagrinėsime ir palyginsime studentų ir dèstytojų požiūrị ị vertinimą.

\section{2 lentelè. Teiginiai apie vertinimo paskirtị}

\begin{tabular}{|c|l|}
\hline 1 & Vertinimas reikalingas tam, kad tobulintų mokymą. \\
\hline 2 & Vertinimas turi teigiamai nuteikti tolesniam mokymuisi. \\
\hline 3 & Vertinimas turi parodyti mokèjimo lygị. \\
\hline 4 & Vertinimas skirtas konstatuoti esamą padètị. \\
\hline 5 & Vertinimas yra skirtas drausminti. \\
\hline 6 & Vertinimas skirtas bausti. \\
\hline 7 & Vertinimas skirtas mokymosi motyvacijai kelti. \\
\hline 8 & Vertinimas skirtas padèti mokytis. \\
\hline 9 & Vertinimas skirtas nustatyti pasiekimus ir pažangą. \\
\hline 10 & Neformalusis vertinimas, pvz., pagyrimas, yra taip pat labai svarbus. \\
\hline
\end{tabular}




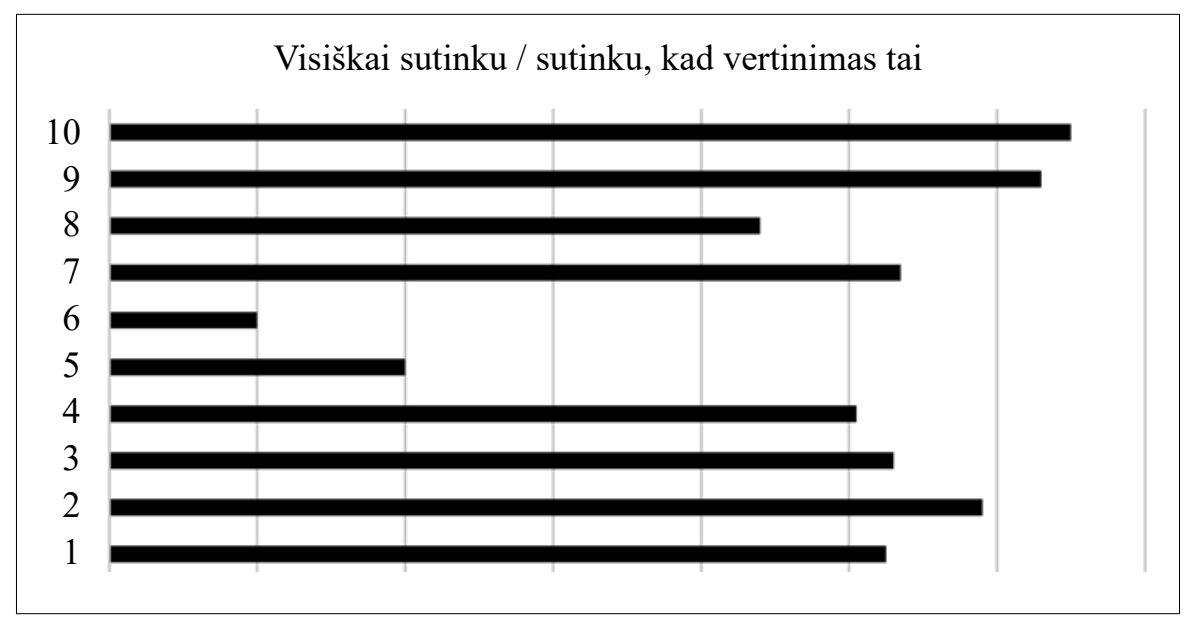

4 pav. Studentų nuomonè, kas yra vertinimas

Teiginys, su kuriuo visiškai sutinka 53 proc. ir sutinka 34 proc. studentų, yra „Neformalusis vertinimas, pvz., pagyrimas, yra taip pat labai svarbus“ (žr. 4 pav.). Šiam teiginiui 100 proc. pritaria ir apklausti UKC dèstytojai (žr. 5 pav.). Taigi, tiek studentai, tiek desstytojai neabejoja neformaliojo vertinimo svarba ir Užsienio kalbos modulio / dalyko pasiekimų vertinimui naudoja ịvairias vertinimo formas: simbolius, taškus, pastabas ar komentarus žodžiu.

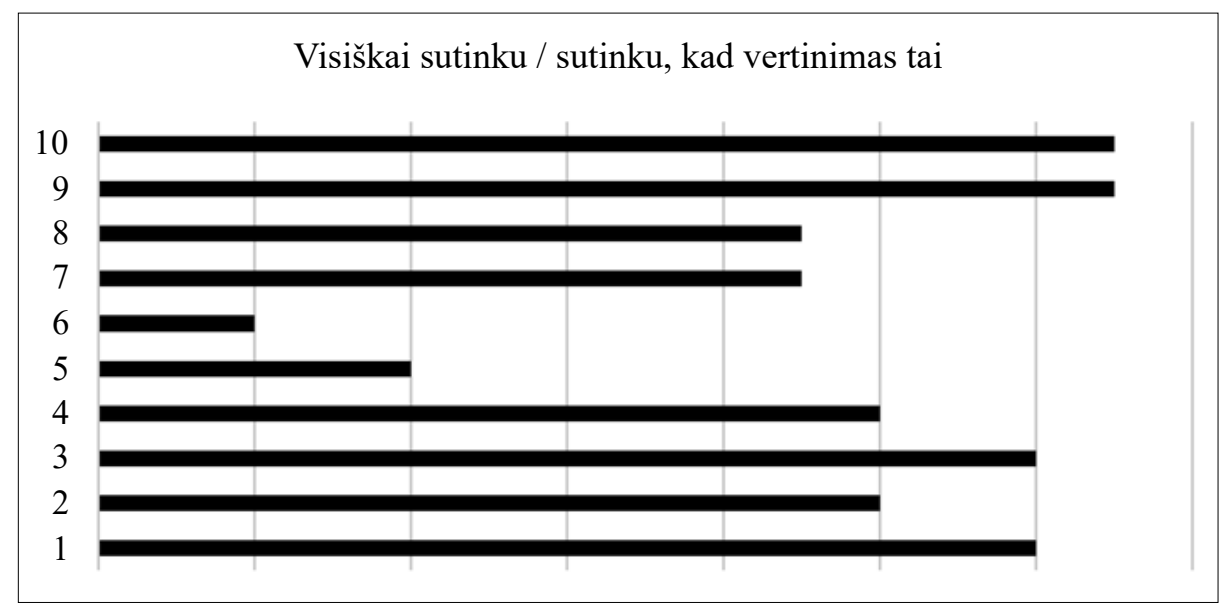

5 pav. Dėstytojų nuomonè, kas yra vertinimas

Tiek studentai, tiek dèstytojai vertinimą supranta kaip priemonę pasiekimams bei pažangai nustatyti. 79 proc. apklaustujų studentų pritaria teiginiui ,Ivertinimas turi teigiamai nuteikti tolesniam mokymuisi“. Daugelis studentu pritaria, kad vertinimas reikalingas mokymui tobulinti ir turi parodyti mokejjimo lygi (žr. 
3 lentelę 1, 3 teiginius), taip pat studentai mano, kad vertinimas skirtas mokymosi motyvacijai kelti. Daugiausia apklaustų dėstytojų pritaria 1, 2, 3, 4 teiginiams (žr. 3 lentelę). Tačiau studentai nepritaria vertinimui kaip drausminimo ir baudimo priemonei: 13 proc. studentų mano, kad vertinimas yra skirtas bausti, o 27 proc. vertinimą supranta kaip drausminimo priemonę, kai tuo tarpu 15 proc. dėstytojų vertinimą supranta kaip bausmę, o 31 proc. dėstytojų mano, kad vertinimas yra taip pat ir drausminimo priemonè. Studentų nuomone, užsienio kalbų dèstytojų vertinimai yra objektyvūs ir nešališki, atspindi mokymosi rezultatus, taip pat vertinimas yra visapusiškas: vertinamos tiek žinios, tiek gebejjimai.

\section{Išvados}

VK EIF ir VVF studentų ir UKC dėstytojų požiūriu, formalusis vertinimas reikalingas mokymuisi tobulinti. Jų nuomone: vertinimas turi teigiamai nuteikti tolesniam mokymuisi ir turi parodyti mokejjimo lygi. Neformalusis vertinimas, pvz., žodinis pagyrimas ar pastaba, studentų ir dèstytojų nuomone, yra taip pat labai svarbūs. Tiek dèstytojai, tiek studentai pritaria teiginiams, kad vertinimas skirtas padèti mokytis ir nustatyti pasiekimus ir pažangą. Tačiau studentų ir dėstytojų nuomoné išsiskyrè dèl vertinimo kaip drausminimo priemonès. Dauguma dėstytojų mano, kad vertinimas skirtas drausminti ir bausti, tuo tarpu didesnè studentų dalis nesutinka su tuo. Tačiau net 39 proc. studentų nurodè, kad vertinimas balais nèra svarbus, o 67 proc. studentų teigia, kad jų užsienio kalbų žinios ir gebejjimai yra vertinami ne tik balais, bet ir simboliais: +, -, taškais, taip pat sulaukia pagyrų ar pastabų žodžiu. Todèl galima teigti, jog šiu VK fakultetu studentai sąmoningai ir noriai mokosi kalbų ne dẻl ịvertinimų, o dèl žinių ir pasiekimų, dèl noro tobulèti ar išmokti naują kalbą.

Tačiau kai kurie faktai reikalauja išsamesnio tyrimo arba patikslinimo, nes i klausimą, ar vertinimas visada parodo tai, ką studentai išmoko, ir ar jis atspindi mokymosi rezultatus, 41 proc. EIF ir 44 proc. VVF studentų, atsakydami ị pirmą klausimą, ir 24 proc. $-i$ antraji, teigia, kad tai vyksta retai arba tik kartais, nors 94 proc. visų apklaustujų (žr. 1 pav.) pritaria teiginiui, kad užsienio kalbos modulio / dalyko vertinimo kriterijai yra aiškūs, 75 proc. jų teigia, jog vertinimas yra sąžiningas ir nešališkas, o 71 proc., kad vertinimas atspindi jų mokymosi rezultatus. Neformalaus pokalbio su studentais metu paaiškejjo, kad daugelis iš jų išmokimą sutapatina su praktine patirtimi, o kadangi savo darbo aplinkoje jie susikalba užsienio kalbomis su klientais ir svečiais, tad ir tvirtina, kad vertinimas neatspindi mokymosi rezultatụ. Bet kaip anksčiau minèjome, šiuos teiginius tikslinsime.

Studentų ịtraukimas ị vertinimo ir įsivertinimo veiklas svarbus vertinimo kultūrai puoselèti, nes tai padeda studentams prisiimti atsakomybę už savo mokymąsi, ugdytis savarankiško mokymosi gebèjimus. „I studentą orientuoto mokymosi, mokymo ir pasiekimų vertinimo dermès" rekomendacijų sąvade patariama studentus aktyviau įtraukti ị vertinimo procesą, leisti išsakyti nuomonę, teikti pasiūlymus, 
diskutuoti apie mokymosi tobulinimą, nes studentai ị aukštąsias mokyklas ịstoja su skirtinga mokymosi patirtimi, gebėjimais ir nevienodai supranta aukštojo mokslo studijas. Apklausų rezultatais, net 83 proc. apklaustųjų pritaria teiginiui, kad užsienio kalbų dalyko / modulio vertinime dalyvauja ir dèstytojai, ir studentai, o užsienio kalbų vertinimo metodas Kalbų pasiekimų aplankas, kurị pildo VVF studentai semestro metu, skatina stebèti pažangą ir numatyti tolesnes tobulejimo galimybes.

VK EIF ir VVF studentams yra aiškūs užsienio kalbos dalyko / modulio vertinimo kriterijai, nors jie kiekvienam tarpiniam atsiskaitymui yra parengiami skirtingi, atsižvelgiant ị studijuojamą programą, ị studentų žinių lygị ir siekiamą rezultatą. Atsižvelgiant ị tai, kad studentai pritaria formaliajam vertinimui, ir ị tai, kad nurodo, jog jie yra vertinami vieną kartą per savaitę, galime daryti prielaidą, kad jiems priimtinas dažnas žinių ir gebejjimų vertinimas, nes tai skatina mokytis, didina mokymosi motyvaciją, padeda suvokti savo žinių lygị ir galimybes, taip pat padeda mokytis iš klaidų. Iš apklausų paaiškejjo, jog studentai mano, kad norėdami padèti ar nukreipti tam tikrai veiklai, dėstytojai ịvertina juos žodžiu arba simboliu, bet ne balu. O balas skirtas formaliajam žinių ir gebejjimų ịvertinimui. Taigi, kaip jau anksčiau teigème, mokant(is) užsienio kalbų vis dar yra svarbus tiek mokymosi rezultatų vertinimas (formalusis), tiek neformalusis vertinimas, skatinantis studentų mokymąsi ir ilgalaikę motyvaciją, o VK dèstytojai ir studentai labai aiškiai supranta formaliojo ir neformaliojo vertinimo paskirti, kai vienas iš jų yra skirtas mokymosi rezultatams fiksuoti, o kitas - pažangai sekti ir motyvacijai skatinti.

\section{Literatūra}

1. Formuojamasis vertinimas - individualiai pažangai skatinti [interaktyvus]. 2018. Prieiga per internetą: <https://www.smm.lt/uploads/documents/Pedagogams/Formuojamasis\%20vertinimas_internetine\%20versija_2018.pdf $>$

2. Formuojamojo vertinimo gairés destytojams ir studentams [interaktyvus]. 2017. Prieiga per internetą: <https://faberasmusdotorg.files.wordpress. com/2017/12/1guidebook_lit.pdf $>$.

3. Holmes, T. 2005. Integrating CLB Assessment in your ESL Classroom. Center for Canadian Language Benchmarks.

4. Raudienè, I. Vertinimas ugdymui [interaktyvus]. Prieiga per internetą: $<$ https://www.smm.lt/uploads/documents/veikla/1/vertinimas_pavaduotojams.pdf $>$

5. I studenta orientuoto mokymosi, mokymo ir pasiekimu vertinimo dermé. Rekomendaciju squadas. [interaktyvus]. 2018. Prieiga per internetą: $<$ http://smpf.lt/ uploads/extra/Rekomendaciju\%20savadas.pdf>

6. Vertinimas ugdymo procese. Knyga mokytojui. Projekto „Vertinimas ugdymo procese“ (2004-2006 m.) patirtis. Vilnius, 2006.

7. „Studijų rezultatų vertinimo tvarkos aprašas“, 2016 m. birželio 9 d. Akademinès tarybos posėdžio nutarimas Nr. ATN-6, pakeitimai patvirtinti $2017 \mathrm{~m}$. gegužès 4 d. nutarimu Nr. ATN-5. 
8. „Vilniaus kolegijos studijų tvarka“, patvirtinta 2016 m. gegužès 4 d. nutarimu Nr. ATN-5, 2016 m. gegužès 4 d. nutarimu Nr. ATN-5, pakeitimai patvirtinti Akademinès tarybos $2016 \mathrm{~m}$. rugsèjo $30 \mathrm{~d}$. nutarimu Nr. ATN-8; $2016 \mathrm{~m}$. lapkričio 23 d. nutarimu Nr. ATN-11; 2016 m. gruodžio 19 d. nutarimu Nr. ATN-12; 2017 m. gegužès 4 d. nutarimu Nr. ATN-5; 2018 m. gegužès 14 d. nutarimu Nr. ATN-8; 2018 m. gruodžio 12 d. Nr. ATN-14. 


\title{
THE ASSESSMENT AS A PART OF FOREIGN LANGUAGE TEACHING AND LEARNING AND AN INDICATOR OF THE PROGRESS AND ACHIEVEMENT FROM THE PERSPECTIVE OF THE STUDENTS AND LECTURERS AT THE FACULTY OF ELECTRONICS AND INFORMATICS AND THE FACULTY OF BUSINESS MANAGEMENT AT THE UNIVERSITY OF APPLIED SCIENCES
}

\author{
Jūratė Helsvig, Aušra Netikšienė, Jūratė Patackaitė \\ University of Applied Sciences
}

\section{Summary}

Student academic achievement is one of the main performance indicators of administrative and teaching staff and student cooperation, which has an impact on the acquisition of graduates' knowledge and skills in the professional environment and competitiveness among the professionals of the same field. Therefore, the alignment of student-centred learning, teaching and achievement assessment is important as stated in the manual of recommendations of the project carried out by the Ministry of Science and Education of the Republic of Lithuania and Education Exchanges Support Foundation in 2018.

The authors of the article do not doubt the relevance of the theme and the following factors the assessment efficiency depend on: properly chosen types of assessment, carefully planned methods of assessment, good assignments and assessment criteria and student and lecturer cooperation. This is characteristic of formal assessment type; however, the authors raise the issue of finding the place for informal assessment in the higher education system, as the whole system of higher education is based on the continuous student development and improvement of lecturers' qualification.

The subject is the assessment as a part of foreign language teaching and learning and an indicator of the progress and achievement from the perspective of the students and lecturers of the Faculty of Electronics and Informatics and Faculty of Business Management at the University of Applied Sciences.

The aim is to clarify the attitude of the students of the Faculty of Electronics and Informatics and the Faculty of Business Management and the lecturers of the Foreign Language Centre of the University of Applied Sciences toward the assessment using the survey and interview methods; to compare the attitude of the lecturers and different year students; and to evaluate the advantages, disadvantages and opportunities of different types of assessment to achieve better foreign language learning outcomes at the University of Applied Sciences. 
The survey showed that grading is important for the students not only because it encourages learning but also helps to understand the level of knowledge and learn from mistakes. In addition, most of the surveyed students indicated the importance of informal assessment. The lecturers stated that assessment is designed to identify achievements and progress and is comprehensive because knowledge and skills are assessed. The lecturers had no doubt about the importance of informal assessment. The assessments of the foreign language lecturers were objective, impartial and comprehensive and reflected learning outcomes; furthermore, both knowledge and skills were assessed. However, the students did not agree with the assessment as a means of disciplining and punishing; they wanted more involvement in the assessment process. Considering the manual of recommendations of the Development of Student-Centred Learning, Teaching and Assessment within Bologna Learning Network of the Education Exchanges Support Foundation project and the results of the survey, the authors presented both positive aspects and the aspects of formal and informal assessment in teaching and learning foreign languages to be improved.

Keywords: assessment, foreign language, achievements, formal assessment, informal assessment.

\section{AUTORIŲ LYDRAŠTIS}

Autoriaus vardas, pavardè: Jūratè Helsvig

Darbo vieta ir pareigos: Vilniaus kolegijos Užsienio kalbų centro lektore

Autoriaus mokslinių interesų sritys: profesinès anglų kalbos mokymas(is), besimokančiojo savarankiškumas

Telefonas ir el. pašto adresas: +370 61488 938, j.helsvig@eif.viko.lt

Autoriaus vardas, pavardė: Aušra Netikšienè

Darbo vieta ir pareigos: Vilniaus kolegijos Užsienio kalbų centro lektore

Autoriaus mokslinių interesų sritys: profesinès anglų kalbos mokymas, IKT kalbų mokyme, projektinis mokymas, XXI amžiaus gebėjimų ugdymas

Telefonas ir el. pašto adresas: +370 68951 951, a.netiksiene@eif.viko.lt

Autoriaus vardas, pavardė: Jūratė Patackaitė

Darbo vieta ir pareigos: Vilniaus kolegijos Užsienio kalbų centro lektorè, Centro vedèja

Autoriaus mokslinių interesų sritys: pedagogika, profesinè kalba, tradiciniai ir netradiciniai užsienio kalbų mokymo metodai, daugiakalbystė

Telefonas ir el. pašto adresas: +370 61577 203, j.patackaite@vvf.viko.lt 


\section{AUTHORS' COVER LETTER}

Author's name and surname: Jūratè Helsvig

Workplace and position: Lecturer, Foreign Languages Centre, University of Applied Sciences

Author's research interests: ESP teaching, learner autonomy

Telephone and e-mail address: +370 61488 938, j.helsvig@eif.viko.lt

Author's name and surname: Aušra Netikšienė

Workplace and position: Lecturer, Foreign Languages Centre, University of Applied Sciences

Author's research interests: ESP teaching, ICT in language teaching, project-based teaching, developing 21 st century skills

Telephone and e-mail address: +37068951 951, a.netiksiene@eif.viko.lt

Author's name and surname: Jūratė Patackaitè

Workplace and position: Lecturer, Head, Foreign Languages Centre, University of Applied Sciences

Author's research interests: pedagogy, professional foreign language, traditional and non-traditional foreign language teaching methods, multilingualism

Telephone and e-mail address: +37061577 203,

j.patackaite@vvf.viko.lt 